\title{
Disputes in Managing Projects: A Case Study of Construction Industry in Vietnam*
}

\author{
Khoa Dang VO ${ }^{1}$, Phong Thanh NGUYEN ${ }^{2}$, Quyen Le Hoang Thuy To NGUYEN ${ }^{3}$
}

Received: June 02, 2020 Revised: July 05, 2020 Accepted: July 12, 2020

\begin{abstract}
The construction industry in developing countries like Vietnam, which incorporates small and medium construction enterprises, is typically more prone to disputes and contract dispute-related lawsuits. A dispute may occur at any time in the life cycle of the project. It is sometimes solved with the intermediation of a lawyer or directly by stakeholders. Understanding the causes of disputes in a construction project not only improves the efficiency of a company but also increases the success of projects. This study was carried out using a questionnaire survey at construction projects in Ho Chi Minh City. Sample data with 117 observations were analyzed to find the disputing factors in construction projects: diversity of working style among the parties; reluctance to work; and poor teamwork. Correlation coefficient on a rank of factors between design consultant and contractor; Design consultant and project owners are positively correlated. The Exploratory Factor Analysis (EFA) analysis identified six groups of factors in construction disputes: cooperation, technology, economics, productivity, information, and behavior. The findings are useful for enterprise practice and provide participants with an overview of sources of dispute. Thus, a more complete risk management plan can be formulated, which will accelerate project progress and improve the likelihood of success.
\end{abstract}

Keywords: Business Administration, Business Economics, Conflict Management, Project Management, Construction Enterprises

JEL Classification Code: M12, M54, L74

\section{Introduction}

Disputes and conflicts are often unavoidable in economic production and business management (Han, 2020; Miharja, Sacipto, Thuy To Nguyen, Nguyen, \& Usanti, 2020; Nguyen, Nguyen, Ngo, \& Nguyen, 2019; Sari, Muhtarom, Nguyen, Nguyen, \& Ansir, 2020). The construction industry, in particular, is characterized by huge sums of capital, long project duration, and the engagement of multiple parties,

\footnotetext{
*Acknowledgements:

The authors acknowledge Ho Chi Minh City Open University, Vietnam, for funding this study.

${ }^{1}$ First Author, Lecturer, Department of Project Management, Ho Chi Minh City Open University, Vietnam. Email: khoa.vd@ou.edu.vn

${ }^{2}$ Assistant Professor, Department of Project Management, Ho Chi

Minh City Open University, Vietnam. Email: phong.nt@ou.edu.vn

${ }^{3}$ Corresponding Author. Assistant Professor, Deputy Director, Office of Cooperation and Research Management, Ho Chi Minh City Open University, Vietnam [Postal Address: 97, Vo Van Tan Street, District 3, Ho Chi Minh City, 724000, Vietnam]

Email: quyen.nlhtt@ou.edu.vn

(c) Copyright: The Author(s)

This is an Open Access article distributed under the terms of the Creative Commons Attribution Non-Commercial License (http://Creativecommons.org/licenses/by-nc/4.0/) which permits unrestricted noncommercial use, distribution, and reproduction in any medium, provided the original work is properly cited.
}

and it is, as a result, a dispute-prone industry. There are more and more jobs involved in construction projects and, despite advanced technologies and more modern machinery, designs, and techniques, the shortcomings of the industry are a threat and show up frequently (Ortega \& Bisgaard, 2000; Vo et al., 2019). The failure of a project can be interpreted as the failure of a contractor to meet the owners' requirements and satisfy them thoroughly. Minor disputes are amicably settled by parties if there is clear evidence and the settlement procedure has been detailed in the signed contract. On the contrary, if neither dispute-related data nor a contractual provision on dispute settlement is available, the resolution time will be prolonged, causing severe damages to the concerned parties. According to Love, Davis, London, and Jasper (2008), conflicts and disputes always occur in the construction industry. In disputes where both parties reach an agreement to each others' benefit, no recourse to the legal framework is necessary. On the other hand, if the parties cannot reconcile their dispute, then the construction contract will be applied for a settlement in accordance with laws, and the court's ruling will be final.

Preventing and limiting the risk of disputes is always better than having to handle and resolve them (Bassarak, Pfister, \& Böhm, 2017; Nguyen, Mai, \& Huynh, 2019; Nguyen, Tran, \& Huynh, 2019). It is sometimes solved with 
the intermediation of a lawyer or directly by stakeholders. Therefore, the signing of contracts among parties is an inevitable procedure. The signed contract is an agreement that specifies the rights and responsibilities of all the parties and reduces unnecessary disputes during project implementation. Nevertheless, it should be taken for granted that there will be disputes in construction projects. Characterized by the engagement of multiple resources (money, labor, machinery, etc.), the construction stage has high exposure to disputes. The implementation of a project requires coordination among many stakeholders, including contractors, designers, project managers, owners, and workers (Nguyen, Likhitruangsilp, \& Onishi, 2018, 2020; Pham, Nguyen, Van Tu, Pham, \& Le, 2019; Sy, Likhitruangsilp, Onishi, \& Nguyen, 2017). The quality, implementation time, and other contractual requirements of the contracting parties can be affected by any matter inside or outside the enterprise. Therefore, having a profound understanding of the reasons for disputes in small and medium-sized companies in the construction industry in Vietnam is useful for the management of projects.

\section{Literature Review}

The construction sector is subject under the influence of many groups inside and outside projects and faces competition (Nguyen, Duong, Nguyen, \& Le, 2020; Pham, Dao, Cho, Nguyen, \& Pham-Hang, 2019; Yogeswaran, Kumaraswamy, \& Miller, 1998). A project includes several people from various backgrounds in construction with the talents and knowledge gathered to work together. In this complex environment, every participant has his/her own goals and wishes to draw the most benefits from the project. The greater number of participants, the more abundant perspectives, business interactions, and debates in both contractual and social relations, which gives rise to disputes. Disputes must be resolved, because any dispute not promptly resolved will lead to claims, counterclaims, and conflicts affecting the implementation of a project, often leading to major financial losses and even litigation.

Most of the disputes in the construction industry related to contracts, which may include untimely contractual payments, quality of contract content, non-serviceable contract information, and unrealistic expectations of the customer (Hansen, 2019; Nguyen, Vo, Phan, Nguyen, \& Huynh, 2019; Vo, Nguyen, \& Le-Hoai, 2019). A dispute may occur when a claim for the rights of one party is denied by another party. Disputes in the construction industry are commonly caused by the speed of construction, the cost and quality control, and scarce capital resources. While disputes are inherent and inevitable in a project, the actual dispute varies from project to project. The main causes of these disputes are derived from errors or omissions in the process of contract documentation, errors in the cost estimators of the initial commitment, changes in conditions, and reactions of customers and/or stakeholders. Environmental features are also taken into account. A survey by Semple, Hartman, and Jergeas (1994) pointed out that the most common causes of disputes were changes in the scope of work, weather, and limited access to the works. The quality of communication and coordination of efforts among project participants (owner, contractor, designer, project manager, etc.) can be a source of dispute (Shin, 2000). The principal relationship between the owner and contractor is considered as the dominant source of disputes. Overspending the budget, increasing the cost of payments, untimely or late payments by the owner, changes in the number of project days, the settlement of debts, design changes, etc. are the leading factors leading to dispute (Cheung \& Suen, 2002). For example, changes in an owner's requirements may affect the contractor's resource plan and raise their risk since profit margins in small projects are typically narrow. The contractor's professional capacity is also a driver of dispute risk. Resource limitations, for example, the lack of time, money, labor, materials, and equipment, are often reasons for intensified tensions in economic and technical contractual relations between a contractor and owner (Harmon, 2003).

The sources of disputes can be divided into two groups, one related to construction techniques and one related to human behavior (Cheung \& Yiu, 2006). Construction technique conflicts arise in the face of cost hiking, an owner not paying for requested changes, and who has the liability to pay for additional costs when a project is extended (such as when the owner is not satisfied with the principal contractor's progress, late technical instructions from a designer, and late payments by the customer). Similar consequences are also addressed in the contractual relationships between the principal and his subcontractors. Disputes also arise from the inefficiencies in the cooperation between the owner principal and the contractor; the principal contractor and the designer, etc. (Fadhlullah Ng, Ismail, \& Hashim, 2019). For example, if the principal contractor delays payments or fails to pay for work outside the contract; the subcontractor may delay its performance due to the impact of work changes or increased work volume. Sources of conflict-related to human behavior include poor negotiation skills, which is reflected when many issues are discussed simultaneously, either or both parties not being well prepared for negotiation, both parties seeking control over the proceedings, unrealistic expectations and a lack of leadership in the project teams, lack of trust and/ or a lack of confidence in the mediator (Huynh, Nguyen, Nguyen, \& Nguyen, 2018; Schweisfurth \& Raasch, 2020; Van Nguyen, Nguyen, Thuy, Nguyen, \& Huynh, 2016).

Many studies have been done on who initiates and why disputes occur. The possibility of having and the degree of influence over the dispute sources have been subject to many studies. In general, the main influence is within the 
responsibility of both the owner and the contractor. The owner's responsibility as a source of disputes typically relates to the failure to pay on time and making changes in the technical specifications of construction products (Khahro \& Ali, 2014; Mahamid, 2016; Mishmish \& ElSayegh, 2018; Narh, Owusu, Oduro-Apeatu, \& Narh, 2015; Sambasivan \& Soon, 2007; Waldron, 2006; Chan \& Suen, 2005; Zaneldin, 2020). On the other hand, some studies have argued that a problem with the contractor is the main source of disputes. A contractor's lack of resources and shortcomings in construction (Toor \& Ogunlana, 2008). In addition to these major reasons derived from the principal relationship between the owner and contractor, researchers have also considered other sources of disputes. Some other studies pointed to the synergistic relationship among the direct members of the project as being at the root of disputes (Zhang \& Huo, 2015).

\section{Research Methodology}

Data was collected from survey questionnaires. The questionnaire content and structure were the results of a pilot study. Each questionnaire was formulated based on a literature review and pilot study that took into account 26 factors affecting construction disputes (see Table 1). The questionnaire for the survey had been adapted to the study environment before the survey was conducted. The 5-level Likert scale was applied $(1=$ strongly disagree, 5 $=$ strongly agree). Cronbach's alpha coefficient was used for the analysis of internal consistency to validate the question items. Descriptive statistical analysis representing the characteristics of respondents were also displayed. In addition, an EFA analysis was conducted to extract the factors that influence construction disputes. Questionnaire respondents were people involved in construction projects in Ho Chi Minh City, Vietnam. The questionnaires were handed out using a convenience sampling approach. They were completed by having direct interviews or feedback from the participants, which included project owners or project management units, design consultants, contractors, and so on.

The study was carried out in two steps as shown in Figure 1: Step 1 described the main components, such as factor identification, pilot study, survey frame design, and data collection. The outcome of step 1 was a dataset related to the research subject-construction disputes. Step 2 concerned data analysis methods that were performed to address the implications of the dataset. They covered the following contents: important factors affecting construction project disputes by mean ranking, the influence of job position on factor rankings by rank correlation analysis, identification of the main factor groups by EFA method. SPSS and Microsoft Excel were used for analysis and the processing of data.
Table 1: Factors affecting construction project disputes

\begin{tabular}{|c|c|}
\hline $\mathbf{I}$ & Behavior factors \\
\hline 1 & Poor communication \\
\hline 2 & Attitude and behavior of managers towards workers \\
\hline 3 & Cultural diversity \\
\hline 4 & Shortage of trust in each other \\
\hline II & Working method and conditions \\
\hline 5 & Poor teamwork \\
\hline 6 & Reluctance to work \\
\hline 7 & Diversity of working style among parties \\
\hline 8 & Changes in the scope of work and weather \\
\hline III & Contractual factors \\
\hline 9 & Untimely contractual payment \\
\hline 10 & Ambiguous provisions \\
\hline 11 & $\begin{array}{l}\text { Non-serviceable contract information, lack of } \\
\text { information }\end{array}$ \\
\hline 12 & $\begin{array}{l}\text { Unrealistic requirements of parties, excessive } \\
\text { demand for benefits }\end{array}$ \\
\hline 13 & $\begin{array}{l}\text { Changes in the initial cost commitment under the } \\
\text { contract }\end{array}$ \\
\hline 14 & Unilateral early termination of the contract \\
\hline IV & Construction technical factors \\
\hline 15 & Contractor's noncompliance with the design \\
\hline 16 & Drawing flaws and negligence in design \\
\hline 17 & The contractor does not meet the schedule \\
\hline 18 & $\begin{array}{l}\text { The owner's arbitrary changes in the design and } \\
\text { technical norms }\end{array}$ \\
\hline $\mathbf{V}$ & Factors related to cost \\
\hline 19 & Sudden increases in cost for materials and fuels \\
\hline 20 & Owner's failure to pay timely \\
\hline 21 & Construction progress behind \\
\hline 22 & Unjustifiable salary \\
\hline VI & Factors related to work experience \\
\hline 23 & Inexperienced negotiators \\
\hline 24 & Parties' lack of legal awareness \\
\hline 25 & Unclear instructions from architects and engineers \\
\hline 26 & A late response to contingencies \\
\hline
\end{tabular}

\section{Results and Discussion}

Three hundred and twenty questionnaires were handed out and 165 samples were collected. Upon collecting the completed questionnaires, four were rejected because they were not filled out completely. There were 117 qualified 


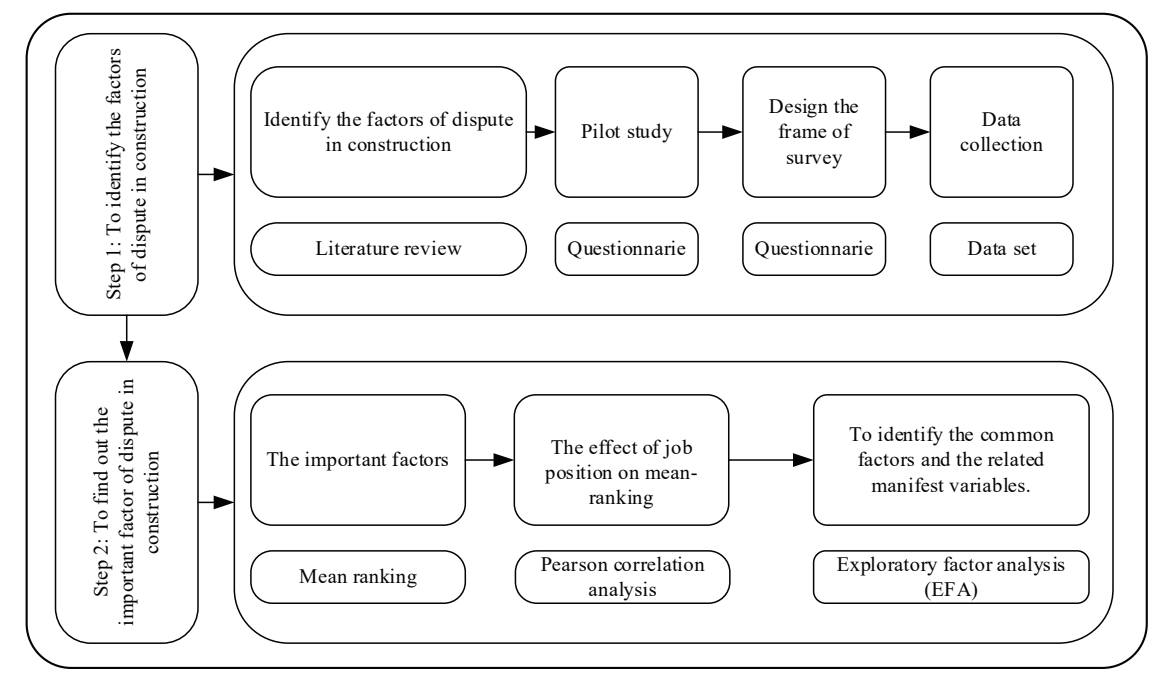

Figure 1: Research framework

samples in total, the minimum sample size for analysis. Information required of the respondents to the questionnaire included gender, current position, work experience as shown in Table 2. There were $95(81.2 \%)$ men and 22 (18.8\%) women. These gender statistics were consistent with the fact that very few women are engaged in the construction industry. Regarding the current position, $50(42.7 \%)$ were design consultants, 22 (18.8\%) were contractors, 22 (18.8\%) were owners and project managers, and 23 (19.7\%) were other participants. Data was obtained from company offices and construction sites. As a result, consulting engineers working at representative offices of a design consultancy company accounted for a large proportion of the respondents. Additionally, $22(18.8 \%)$ people had less than 5 years of experience, $49(41.9 \%)$ had from 5 to 10 years of experience, $31(26.5 \%)$ had from 10 to 15 years, and $15(12.8 \%)$ had more than 15 years of experience in construction industry. The experience distribution gave a sound reflection on the survey information.

The average ranking of the 26 factors affecting construction project disputes is presented in Table 3. The top five factors were: Diversity of working style among parties (mean $=3.82 ; \mathrm{R}=1)$, Reluctance to work (mean = 3.74; $R=2)$, Poor teamwork (mean $=3.68 ; R=3)$, Spiking costs for materials and fuels (mean $=3.67, R=4)$, and Nonserviceable contract information, lack of information (mean $=3.65, \mathrm{R}=5$ ). "Diversity of working style among parties" indicates that the coordination effort of parties was prone to dispute. Collaboration in a project is influenced by several different actors, including the corporate culture, the sense of personal responsibility at work, task determination, and the assignment system, etc. These influences can lead to negative consequences in the project implementation.
Table 2: Sample characteristics

\begin{tabular}{|l|c|c|}
\hline \multicolumn{1}{|c|}{ Description } & Frequency & Percent (\%) \\
\hline Gender & & \\
\hline Male & 95 & 81.2 \\
\hline Woman & 22 & 18.8 \\
\hline Working position & & \\
\hline Design consultant & 50 & 42.7 \\
\hline Contractor & 22 & 18.8 \\
\hline Owner/project manager & 22 & 18.8 \\
\hline Others & 23 & 19.7 \\
\hline Experience & & \\
\hline$<5$ years & 22 & 18.8 \\
\hline 5- 10 years & 49 & 41.9 \\
\hline 10- 15 years & 31 & 26.5 \\
\hline$>15$ years & 15 & 12.8 \\
\hline Total & 117 & 100 \\
\hline
\end{tabular}

"Reluctance to work" refers to the personal productivity of the project participants. Individual characteristics of each participant may influence his or her, level of engagement, which in turn affects the performance of individuals, teams, and the whole project. "Poor teamwork" refers to the coordination in the team's internal affairs. Team performance, which is affected by the coordination of members, impacts other project stakeholders. Since the project is a workflow, the design product quality may affect the construction process, or the construction quality may affect the owner's project operational plan. "A spike in material and fuel costs" is an 
Table 3: Rankings of factors affecting construction disputes

\begin{tabular}{|l|l|c|c|c|}
\hline \multicolumn{1}{|c|}{ Factors } & SD & Mean & Rank \\
\hline Prod3 & Diversity of working style among parties & 0.83 & 3.82 & 1 \\
\hline Prod2 & Reluctance to work & 0.73 & 3.74 & 2 \\
\hline Prod1 & Poor teamwork & 0.86 & 3.68 & 3 \\
\hline Eco1 & Sudden increase in cost for materials and fuels & 0.78 & 3.67 & 4 \\
\hline Co5 & Non-serviceable contract information, lack of information & 0.83 & 3.65 & 5 \\
\hline Eco2 & Unjustifiable salary & 0.86 & 3.63 & 6 \\
\hline Eco3 & Construction progress behind the schedule & 0.88 & 3.6 & 7 \\
\hline Co6 & Unrealistic requirements of parties, excessive demand for benefits & 0.85 & 3.6 & 8 \\
\hline Prod4 & Changes in the scope of work and weather & 0.892 & 3.59 & 9 \\
\hline Be2 & Cultural diversity & 0.8 & 3.6 & 10 \\
\hline Eco4 & Owner's failure to pay timely & 0.95 & 3.56 & 11 \\
\hline Be1 & Poor communication & 0.8 & 3.56 & 11 \\
\hline Co3 & Untimely contractual payment & 0.87 & 3.55 & 13 \\
\hline Co4 & Ambiguous provisions & 0.85 & 3.53 & 14 \\
\hline Co1 & Unilateral early termination of contract & 0.88 & 3.48 & 15 \\
\hline Co2 & Changes in the initial cost commitment under the contract & 0.91 & 3.48 & 16 \\
\hline Be3 & Shortage of trust in each other & 0.97 & 3.38 & 17 \\
\hline Tech1 & The contractor does not meet the schedule & 1 & 3.31 & 18 \\
\hline Tech3 & The owner's arbitrary changes in the design and technical norms & 1.01 & 3.31 & 18 \\
\hline Tech2 & Drawing flaws and negligence in design & 1.02 & 3.28 & 20 \\
\hline Tech4 & Contractor's discompliance with the design & 1.03 & 3.24 & 21 \\
\hline Inf4 & Parties' lack of legal awareness & 1.04 & 3.22 & 22 \\
\hline Inf1 & Unclear instructions from architects and engineers & 1.06 & 3.21 & 23 \\
\hline Be4 & Attitude and behavior of managers towards workers & 0.98 & 3.17 & 24 \\
\hline Inf2 & Inexperienced negotiators & 0.99 & 3.17 & 25 \\
\hline Inf3 & Late response to contingencies & 1.01 & 3.14 & 26 \\
\hline
\end{tabular}

objective factor that can arise from the material suppliers or from the market where the work is built. When costs rise, it is a challenge to handle the allocation of responsibilities. If the challenge is not resolved satisfactorily among project parties, a dispute is unavoidable. "Non-serviceable contract information or a lack of information" is one of the most important bases for the settlement of disputes. It reflects an ability to assess and manage risks through the formulation of contract provisions that deal with contingencies under the contract. When the contract information is not serviceable and not enough information is provided, a dispute will be unavoidable.

How extensively a factor affects disputes in a construction project depends on the perspective of the project participants. In particular, design consultants, contractors, or project owners or managers have diverse viewpoints that influence a dispute. The factor rankings distinguish three groups of respondents. The ranking correlation is analyzed to explore the correlation among viewpoints of the parties to the dispute. Spearman's rho correlation coefficient is shown in Table 4.

Design consultants and contractors are positively correlated with how they assess factors affecting construction disputes. This correlation is quite strong $(r=0.788)$ with a high statistical significance of $p<0.01$. The correlation between design consultants and owners or project managers on the evaluation of construction dispute factors is positive $(\mathrm{r}=0.454, \mathrm{p}<0.05)$. In contrast, the correlation between contractors and owners or project managers and their assessment of influential factors in creating disputes is not statistically significant $(r=0.343, p>0.05)$. 
Table 4: The Spearman's rho correlations

\begin{tabular}{|c|c|c|c|c|c|}
\hline \multirow{2}{*}{ Spearman's rho } & & & Design & Contractor & Owner \\
\hline & \multirow[t]{3}{*}{ Design } & Correlation Coefficient & 1.000 & $.788^{* *}$ & $.454^{*}$ \\
\hline & & Sig. (2-tailed) & & .000 & .020 \\
\hline & & $\mathrm{N}$ & 26 & 26 & 26 \\
\hline & \multirow[t]{3}{*}{ Contractor } & Correlation Coefficient & $.788^{* *}$ & 1.000 & .343 \\
\hline & & Sig. (2-tailed) & .000 & . & .086 \\
\hline & & $\mathrm{N}$ & 26 & 26 & 26 \\
\hline & \multirow[t]{3}{*}{ Owner } & Correlation Coefficient & $.454^{*}$ & .343 & 1.000 \\
\hline & & Sig. (2-tailed) & .020 & .086 & . \\
\hline & & $\mathrm{N}$ & 26 & 26 & 26 \\
\hline \multicolumn{6}{|c|}{ **. Correlation is significant at the 0.01 level (2-tailed). } \\
\hline \multicolumn{6}{|c|}{ *. Correlation is significant at the 0.05 level (2-tailed). } \\
\hline
\end{tabular}

The above-ranking correlation reveals the correlation among parties in their ranking of factors affecting construction disputes. In particular, design consultants' assessment of factors were more consistent with the contractors than with the owners or project managers. Their similar occupational characteristics, engagement in the same field of construction, and their similar roles as construction service providers explain this consistency. On the other hand, there was no correlation between contractors and owners or project managers in their assessment of influential factors. That they did not share a point of view is understandable, as it reflects each of their distinctive perspectives on project implementation, and disputes can occur from the diversity in the way each attempts to achieve goals.

Cronbach's Alpha analysis for each group was conducted. Cronbach's Alpha coefficient of group Eco (0.928) covered 4 items, group Tech (0.917) included 4 items, group Pro. (0.916) included 4 items, Group Co. (0.947) covered 6 items, group inf (0.886) included 4 items, group Be $(0.686)$ had 4 items. Be4 was removed from group Be because it had a total correlation of 0.052 . The Cronbach's Alpha coefficient of the Be group with 3 items was 0.877 . The Cronbach's Alpha coefficient of the whole scale with 25 items was 0.899 . The 25 variables were integrated into the analysis as the main factors. KMO verification (Kaiser - Mayer - Olkin) and Bartlett's Test of Sphericity were conducted to check the relevance of data before EFA analysis was performed as shown in Table 5. KMO $=0.739$, sig. value of Bartlett's test of sphericity $=0.000$. This indicated that the data was suitable for analysis. The EFA analysis was conducted with 25 observable variables and reduced by the principal component analysis (PCA) method using the Varimax rotation.

The tests came up with 6 groups of factors at a cumulative total variance explained of $81.523 \%$ as shown in Table 6. It has an internal eigenvalue value less than 1.0 as shown in the
Table 5: KMO and Bartlett's test results

\begin{tabular}{|c|c|c|}
\hline \multicolumn{2}{|c|}{$\begin{array}{l}\text { Kaiser-Meyer-Olkin Measure of Sampling } \\
\text { Adequacy. }\end{array}$} & .739 \\
\hline \multirow{3}{*}{$\begin{array}{l}\text { Bartlett's Test of } \\
\text { Sphericity }\end{array}$} & Approx. Chi-Square & 3040.103 \\
\hline & $d f$ & 300 \\
\hline & Sig. & .000 \\
\hline
\end{tabular}

\section{Scree Plot}

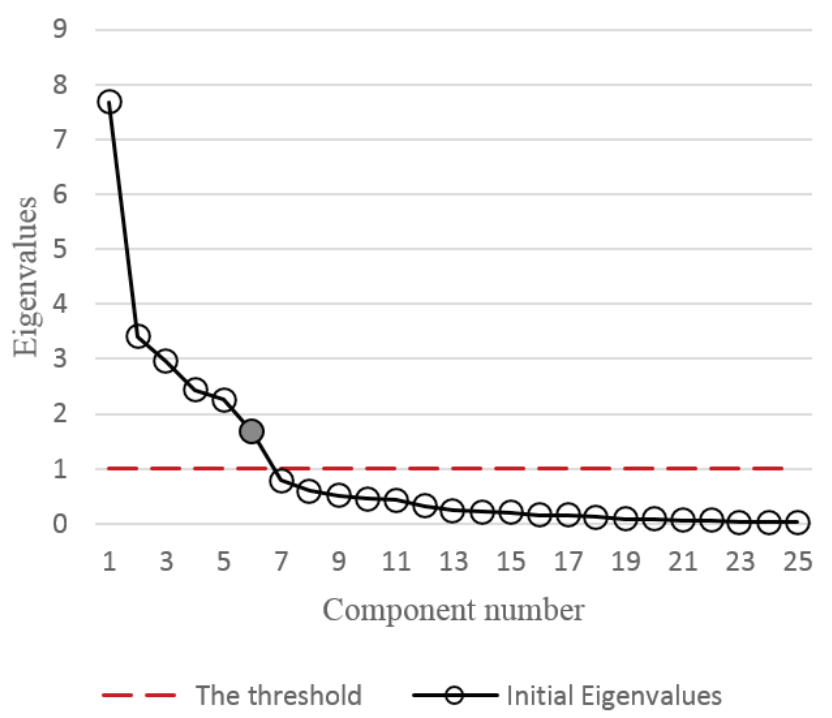

Figure 2: Scree Plot

scree plot in Figure 2. The factor loading for each component is presented in Table 7. Six groups of factors were named as follows: co-operate-related; economy-related; productiverelated; technology-related; information-related; and behavior-related. 
Table 6: Total Variance Explained

\begin{tabular}{|c|c|c|c|c|c|c|c|c|c|}
\hline \multirow{2}{*}{ Component } & \multicolumn{3}{|c|}{ Initial Eigenvalues } & \multicolumn{3}{|c|}{$\begin{array}{l}\text { Extraction Sums of Squared } \\
\text { Loadings }\end{array}$} & \multicolumn{3}{|c|}{$\begin{array}{c}\text { Rotation Sums of Squared } \\
\text { Loadings }\end{array}$} \\
\hline & Total & $\begin{array}{c}\% \text { of } \\
\text { Variance }\end{array}$ & $\begin{array}{c}\text { Cumulative } \\
\%\end{array}$ & Total & $\begin{array}{c}\% \text { of } \\
\text { Variance }\end{array}$ & $\begin{array}{c}\text { Cumulative } \\
\%\end{array}$ & Total & $\begin{array}{c}\% \text { of } \\
\text { Variance }\end{array}$ & $\underset{\%}{\text { Cumulative }}$ \\
\hline 1 & 7.673 & 30.690 & 30.690 & 7.673 & 30.690 & 30.690 & 4.896 & 19.583 & 19.583 \\
\hline 2 & 3.406 & 13.622 & 44.312 & 3.406 & 13.622 & 44.312 & 3.357 & 13.428 & 33.011 \\
\hline 3 & 2.957 & 11.827 & 56.140 & 2.957 & 11.827 & 56.140 & 3.352 & 13.407 & 46.418 \\
\hline 4 & 2.419 & 9.677 & 65.817 & 2.419 & 9.677 & 65.817 & 3.280 & 13.120 & 59.538 \\
\hline 5 & 2.264 & 9.054 & 74.871 & 2.264 & 9.054 & 74.871 & 3.022 & 12.086 & 71.624 \\
\hline 6 & 1.663 & 6.652 & 81.523 & 1.663 & 6.652 & 81.523 & 2.475 & 9.899 & 81.523 \\
\hline 7 & .795 & 3.182 & 84.704 & & & & & & \\
\hline 8 & .592 & 2.369 & 87.073 & & & & & & \\
\hline 9 & .519 & 2.078 & 89.151 & & & & & & \\
\hline 10 & .453 & 1.811 & 90.962 & & & & & & \\
\hline 11 & .425 & 1.702 & 92.663 & & & & & & \\
\hline 12 & .323 & 1.293 & 93.956 & & & & & & \\
\hline 13 & .250 & .999 & 94.955 & & & & & & \\
\hline 14 & .223 & .890 & 95.846 & & & & & & \\
\hline 15 & .202 & .807 & 96.653 & & & & & & \\
\hline 16 & .163 & .651 & 97.304 & & & & & & \\
\hline 17 & .142 & .566 & 97.870 & & & & & & \\
\hline 18 & .125 & .501 & 98.371 & & & & & & \\
\hline 19 & .087 & .349 & 98.720 & & & & & & \\
\hline 20 & .084 & .336 & 99.056 & & & & & & \\
\hline 21 & .068 & .273 & 99.328 & & & & & & \\
\hline 22 & .065 & .260 & 99.589 & & & & & & \\
\hline 23 & .040 & .162 & 99.751 & & & & & & \\
\hline 24 & .035 & .138 & 99.889 & & & & & & \\
\hline 25 & .028 & .111 & 100.000 & & & & & & \\
\hline
\end{tabular}

The co-operate-related group includes 6 items with a variance of $19.583 \%$. This group of factors reflected the collaboration of parties in production activities or the settlement of disputes, which has a major impact on construction disputes. The technology-related group includes 4 items with a variance of $13.428 \%$. This group impacts matters related to construction service quality that comes from contractors or designers. This group is the second most important rationale for factors affecting construction project disputes. The economy-related, productive-related, and informationrelated groups all share the same level of importance with explained variances of $13.407 \%, 13.120 \%$, and $12.086 \%$, respectively. The economy-related group includes 4 items regarding the contractor's financial position as it relates to an owner's delayed payments, materials price, and its financial controls and progress. The productive-related group covers 4 items concerning the productivity of individuals involved in the project. It is influenced by the individual characteristics, an institution's working manner, and the natural adverse conditions. The information-related group consists of 4 items, including those that relate to a lack of work instructions, job communication, or response to emergencies, all of which harm the project. The behavior-related group is the last and it includes three factors with an explained variance of $9.899 \%$. This group of factors is linked to human behavior, including trust, communication, and cultural diversity. 
Table 7: Factor loadings for each component affecting construction disputes

\begin{tabular}{|c|c|c|c|}
\hline Code & Component & loading & $\%$ of variance \\
\hline & Co-operate-related & & 19.583 \\
\hline Co1 & Unilateral early termination of contract & 0.894 & \\
\hline Co3 & Untimely contractual payment & 0.887 & \\
\hline $\mathrm{Co} 2$ & Changes in the initial cost commitment under the contract & 0.873 & \\
\hline Co4 & Ambiguous provisions & 0.857 & \\
\hline Co5 & Non-serviceable contract information, lack of information & 0.848 & \\
\hline \multirow[t]{2}{*}{ Co6 } & Unrealistic requirements of parties, excessive demand for benefits & 0.824 & \\
\hline & Technology-related & & 13.428 \\
\hline Tech1 & The contractor does not meet the schedule & 0.920 & \\
\hline Tech2 & Drawing flaws and negligence in design & 0.913 & \\
\hline Tech3 & The owner's arbitrary changes in the design and technical norms & 0.841 & \\
\hline \multirow[t]{2}{*}{ Tech4 } & Contractor's discompliance with the design & 0.792 & \\
\hline & Economy-related & & 13.407 \\
\hline Eco1 & Sudden increase in cost for materials and fuels & 0.927 & \\
\hline Eco3 & Construction progress behind the schedule & 0.887 & \\
\hline Eco2 & Unjustifiable salary & 0.875 & \\
\hline \multirow[t]{2}{*}{ Eco4 } & Owner's failure to pay timely & 0.850 & \\
\hline & Productive- related & & 13.120 \\
\hline Prod1 & Poor teamwork & 0.923 & \\
\hline Prod2 & Reluctance to work & 0.875 & \\
\hline Prod4 & Changes in the scope of work and weather & 0.839 & \\
\hline \multirow[t]{2}{*}{ Prod3 } & Diversity of working style among parties & 0.834 & \\
\hline & Information- related & & 12.086 \\
\hline Inf1 & Unclear instructions from architects and engineers & 0.899 & \\
\hline Inf2 & Inexperienced negotiators & 0.882 & \\
\hline $\operatorname{lnf} 4$ & Parties' lack of legal awareness & 0.803 & \\
\hline \multirow[t]{2}{*}{ Inf3 } & Late response to contingencies & 0.798 & \\
\hline & Behavior- related & & 9.899 \\
\hline $\mathrm{Be} 1$ & Poor communication & 0.906 & \\
\hline $\mathrm{Be} 2$ & Cultural diversity & 0.853 & \\
\hline \multirow[t]{2}{*}{$\mathrm{Be} 3$} & Shortage of trust in each other & 0.811 & \\
\hline & Cumulative $\%$ of Variance & & 81.523 \\
\hline
\end{tabular}

\section{Conclusions}

Disputes in construction projects have received substantial attention from researchers. A thorough understanding of the factors affecting project disputes will boost project effectiveness and the satisfaction of the parties involved. This study explored factors that affect disputes in construction projects in Ho Chi Minh City. Then, an analysis of the factors that influence disputes was also conducted to determine the correlations among the different parties. The analysis determined that when ranking the influential factors of disputes the correlation between design consultants and contractors was stronger than that between design consultants and project owners or project managers. The research results showed that there was no correlation between the viewpoints of contractors and owners or project managers. Six groups of 
factors were comprised of 25 items, covering issues ranging from cooperation, technology, economics, productivity, information to behavior.

\section{References}

Bassarak, C., Pfister, H. R., \& Böhm, G. (2017). Dispute and morality in the perception of societal risks: Extending the psychometric model. Journal of Risk Research, 20(3), 299-325. doi:10.1080/13669877.2015.1043571

Chan, E. H. W., \& Suen, H. C. H. (2005). Dispute resolution management for international construction projects in China. Management Decision, 43(4), 589-602. https://doi. org/10.1108/00251740510593576

Cheung, S.-O., \& Suen, H. C. (2002). A multi-attribute utility model for dispute resolution strategy selection. Construction Management \& Economics, 20(7), 557-568.

Cheung, S. O., \& Yiu, T. W. (2006). Are construction disputes inevitable? Ieee Transactions on Engineering Management, 53(3), 456-470.

Fadhlullah Ng, N. K. M., Ismail, Z., \& Hashim, F. (2019). Towards sustainable dispute resolution: A framework to enhance the application of fast track arbitration in the malaysian construction industry. International Journal of Sustainable Construction Engineering and Technology, 10(2), 93-103. doi:10.30880/ ijscet.2019.10.02.009

Han, J. H. (2020). The effects of personality traits on subjective well-being and behavioral intention associated with serious leisure experiences. Journal of Asian Finance, Economics and Business, 7(5), 167-176. https://doi.org/10.13106/jafeb.2020. vol7.no5.167

Hansen, S. (2019). Challenging arbitral awards in the construction industry: Case study of infrastructure disputes. Journal of Legal Affairs and Dispute Resolution in Engineering and Construction, 11(1). doi:10.1061/(ASCE)LA.19434170.0000281

Harmon, K. M. (2003). Conflicts between owner and contractors: Proposed intervention process. Journal of Management in Engineering, 19(3), 121-125.

Huynh, V. D. B., Nguyen, P. V., Nguyen, Q. L. H. T. T., \& Nguyen, P. T. (2018). Application of fuzzy analytical hierarchy process based on geometric mean method to prioritize social capital network indicators. International Journal of Advanced Computer Science and Applications, 9(12), 182-186.

Khahro, S. H., \& Ali, T. H. (2014). Causes leading to conflicts in construction projects: A viewpoint of pakistani construction industry. Paper presented at the International Conference on challenges in IT, Engineering and Technology (ICCIET'2014) July.

Love, P., Davis, P., London, K., \& Jasper, T. (2008). Causal modelling of construction disputes. Paper presented at the Proceedings of the 24th Annual Conference of ARCOM (Association of Researchers in Construction Management).
Mahamid, I. (2016). Micro and macro level of dispute causes in residential building projects: Studies of saudi arabia. Journal of King Saud University-Engineering Sciences, 28(1), 12-20.

Miharja, M., Sacipto, R., Thuy To Nguyen, Q. L. H., Nguyen, P. T., \& Usanti, T. P. (2020). How interactional justice within organisations impacts counterproductive work behaviours and self-efficacy in the presence of performance appraisal satisfaction. International Journal of Innovation, Creativity and Change, 10(11), 459-477.

Mishmish, M., \& El-Sayegh, S. M. (2018). Causes of claims in road construction projects in the uae. International Journal of Construction Management, 18(1), 26-33.

Narh, O. C., Owusu, E. E., Oduro-Apeatu, K., \& Narh, T.-W. J. (2015). An exploratory study of professional conflicts and disputes within the construction industry. International Journal of Managerial Studies and Research, 3(12), 44-65.

Nguyen, H. M., Mai, L. T., \& Huynh, T. L. (2019). The role of transformational leadership toward work performance through intrinsic motivation: A study in the pharmaceutical field in vietnam. Journal of Asian Finance, Economics and Business, 6(4), 201-212. doi:10.13106/jafeb.2019.vol6.no4.201

Nguyen, H. M., Nguyen, C., Ngo, T. T., \& Nguyen, L. V. (2019). The effects of job crafting on work engagement and work performance: A study of vietnamese commercial banks. Journal of Asian Finance, Economics and Business, 6(2), 189201. doi:10.13106/jafeb.2019.vol6.no2.189

Nguyen, M. H., Tran, B. T., \& Huynh, L. T. (2019). Relation between employees and customers affects to the positive word of mouth through customer satisfaction. Journal of Distribution Science, 17(6), 65-75. doi:10.15722/JDS.17.6.201906.65

Nguyen, P. T., Duong, M. T. H., Nguyen, L. T., \& Le, L. P. (2020). Applying design-build approach to construction and engineering project management. International Journal of Advanced Science and Technology, 29(3 Special Issue), 13191327.

Nguyen, P. T., Likhitruangsilp, V., \& Onishi, M. (2018). Prioritizing factors affecting traffic volume of public-private partnership infrastructure projects. International Journal of Engineering and Technology, 7(4), 2988-2991. doi:10.14419/ijet.v7i4.13357

Nguyen, P. T., Likhitruangsilp, V., \& Onishi, M. (2020). Success factors for public-private partnership infrastructure projects in vietnam. International Journal on Advanced Science, Engineering and Information Technology, 10(2), 858-865. doi:10.18517/ijaseit.10.2.5839

Nguyen, P. T., Vo, K. D., Phan, P. T., Nguyen, Q. L. H. T. T., \& Huynh, V. D. B. (2019). Optimization of main factors affecting construction waste by the supply chain management. International Journal of Supply Chain Management, 8(5), 275278.

Ortega, I., \& Bisgaard, S. (2000). Quality improvement in the construction industry: Three systematic approaches. Total Quality Management, 11(4-6), 383-392.

Pham, H. C., Dao, N. N., Cho, S., Nguyen, P. T., \& Pham-Hang, A. T. (2019). Construction hazard investigation leveraging object 
anatomization on an augmented photoreality platform. Applied Sciences, 9(21). doi:10.3390/app9214477

Pham, V. Q., Nguyen, B. K. Q., Van Tu, B., Pham, H. T. T., \& Le, T. Q. (2019). Critical success factors of project management: The case of construction related projects in vietnam. Journal of Asian Finance, Economics and Business, 6(2), 223-230. doi:10.13106/jafeb.2019.vol6.no2.223

Sambasivan, M., \& Soon, Y. W. (2007). Causes and effects of delays in malaysian construction industry. International Journal of Project Management, 25(5), 517-526.

Sari, Y., Muhtarom, A., Nguyen, Q. L. H. T. T., Nguyen, P. T., \& Ansir. (2020). Predictors of job performance: Moderating role of conscientiousness. International Journal of Innovation, Creativity and Change, 11(6), 135-152. http://eprints.ulm.ac.id/ $\mathrm{id} /$ eprint/9558

Schweisfurth, T. G., \& Raasch, C. (2020). Caught between the users and the firm: How does identity conflict affect employees' innovative behavior. Creativity and Innovation Management. [Online First] doi:10.1111/caim.12380

Semple, C., Hartman, F. T., \& Jergeas, G. (1994). Construction claims and disputes: Causes and cost/time overruns. Journal of Construction Engineering and Management, 120(4), 785-795.

Shin, K.-C. (2000). Identification of critical dispute characteristics (cdcs) during construction project operations. School of Civil and Environmental Engineering, Georgia Institute of Technology, Atlanta, GA.

Sy, D. T., Likhitruangsilp, V., Onishi, M., \& Nguyen, P. T. (2017). Impacts of risk factors on the performance of public-private partnership transportation projects in vietnam. ASEAN Engineering Journal, 7(2), 30-52.
Toor, S. U. R., \& Ogunlana, S. O. (2008). Problems causing delays in major construction projects in thailand. Construction Management and Economics, 26(4), 395-408.

Van Nguyen, P., Nguyen, P. T., Thuy, Q. L. H., Nguyen, T., \& Huynh, V. D. B. (2016). Calculating weights of social capital index using analytic hierarchy process. International Journal of Economics and Financial Issues, 6(3), 1189-1193.

Vo, K. D., Nguyen, P. T., \& Le-Hoai, L. (2019). The difference in personality traits of construction engineers in vietnam using the kts instrument. Suranaree Journal of Science and Technology, 26(2), 232-239.

Vo, K. D., Nguyen, P. T., Pham, C. P., Huynh, V. D. B., Nguyen, Q. L. H. T. T., Vu, N. B., \& Le, L. P. (2019). Measuring individual job performance of project managers using fuzzy extended analytic method. International Journal of Recent Technology and Engineering, 8(2 Special Issue), 86-90. doi:10.35940/ijrte. a1379.078219

Waldron, B. D. (2006). Scope for improvement: A survey of pressure points in australian construction and infrastructure projects. A Report Prepared for the Australian Constructors Association by Blake Dawson Waldron Lawyers, Sydney, Australia.

Yogeswaran, K., Kumaraswamy, M. M., \& Miller, D. R. (1998). Claims for extensions of time in civil engineering projects. Construction Management \& Economics, 16(3), 283-293.

Zaneldin, E. K. (2020). Investigating the types, causes and severity of claims in construction projects in the UAE. International Journal of Construction Management, 20(5), 385-401. https:// doi.org/10.1080/15623599.2018.1484863

Zhang, L., \& Huo, X. (2015). The impact of interpersonal conflict on construction project performance. International Journal of Conflict Management, 26(4), 479-498. https://doi.org/10.1108/ IJCMA-09-2014-0072 